\title{
Public Service Logic: An Appropriate Recipe for Improving Serviceness in the Public Sector?
}

\author{
Mette Sønderskov *(D) and Rolf Rønning
}

check for

updates

Citation: Sønderskov, Mette, and Rolf Rønning. 2021. Public Service Logic: An Appropriate Recipe for Improving Serviceness in the Public Sector? Administrative Sciences 11: 64 . https://doi.org/10.3390/ admsci11030064

\section{Received: 30 April 2021}

Accepted: 26 June 2021

Published: 29 June 2021

Publisher's Note: MDPI stays neutral with regard to jurisdictional claims in published maps and institutional affiliations.

Copyright: (c) 2021 by the authors. Licensee MDPI, Basel, Switzerland. This article is an open access article distributed under the terms and conditions of the Creative Commons Attribution (CC BY) license (https:// creativecommons.org/licenses/by/ $4.0 /)$.
Inland School of Business and Social Sciences, Inland Norway University of Applied Sciences, 2624 Lillehammer, Norway; rolf.ronning@inn.no

* Correspondence: mette.sonderskov@inn.no

\begin{abstract}
Researchers have made efforts to combine service management theory with public administration theory to develop an enhanced model of public service logic and help the public sector to develop services through co-creation with service users. This study considered the appropriateness of public service logic for improving serviceness in the public sector, examining the question through a literature review regarding the main elements of service management in which public service logic is anchored. We found no correspondences between this approach and theories on street-level bureaucracy, despite both perspectives aiming to understand the interactions between users and public service providers, and we wanted to explore this gap. We argue that public sector logic neglects important contextual factors, such as the role of public value and politics. Moreover, street-level bureaucrats have a legitimate responsibility not only to provide user-friendly services (creating value for users) but also, occasionally, to overrule citizens' wishes and needs (following political decisions). We conclude that public service logic does not support the development of more serviceness in the public sector context, because it needs to consider the justification for having a public sector. Further research should consider users as collective citizens rather than individuals.
\end{abstract}

Keywords: public administration; service management; public service logic; street-level bureaucracy; public value; co-creation; co-destruction

\section{Introduction}

In their important paper 'It Takes Two to Tango', Osborne and Strokosch (2013) discussed how elements of service management, derived from general management theory and based on market thinking, can be integrated with public administration perspectives in the study of co-production of services. They proposed a model for enhanced co-production, the aim of which was 'user-led innovation of new forms of public services' (p. 37). In later works, Osborne $(2018,2021)$ described this preferred model as public service logic, using the service management perspectives presented by Vargo and Lusch $(2008,2016)$ and Grönroos (2019) as theoretical starting points. This stream of literature focused on how public services can add value for users through co-creation processes, assuming interactive and dynamic relationships between users and service providers (Osborne 2018). Grönroos (2019) claimed that public sector organisations can be as service oriented and user-friendly as their private counterparts, but the lack of competition price mechanisms often causes public managers and policymakers to 'lose focus', resulting in 'inefficiency and an inward-focused management, leadership, and culture' (p. 787). Accordingly, Osborne (2021, p. 135) stated: 'Public policy needs to embrace the idea that citizens should expect to be satisfied with public service encounters ... No private sector service would dream of designing a service where the service encounter left the customer unhappy and dissatisfied'. Osborne thus placed himself and public service logic within the service management tradition.

There is a need to expand knowledge about value creation in different service settings (Hodgkinson et al. 2017). We responded to this call for research by investigating the 
possibilities and limitations of public service logic compared to contributions from the public administration tradition, represented by Lipsky (1980) seminal work on streetlevel bureaucracy and recent follow-up studies (Gofen 2014; Hupe and Buffat 2014; Nothdurfter and Hermans 2018; Tummers et al. 2015; Zacka 2017). Street-level bureaucrats are frontline employees who work directly with individual citizens (Hupe and Buffat 2014). Research on street-level bureaucrats has addressed the dilemmas faced by frontline public service employees and their use of discretion (Nothdurfter and Hermans 2018). Despite the commonalities (i.e., studying interactions between the users and providers of public services), we found no correspondences between public service logic and street-level bureaucracy approaches. While the former emphasises co-creation, focusing on users' interests and needs, the latter focuses on frontline employees' interactions with users within certain organisational and institutional frames. It is important to note that public frontline employees have a legitimate responsibility not only to provide a service but also, occasionally, to overrule citizens' wishes. Regulatory and coercive services are important parts of the public sector. Despite these fundamental differences between private customers in a market and recipients of public services, the service management literature has largely neglected the public sector context (Hodgkinson et al. 2017). Osborne (2018, 2021), in recent works, paid attention to the distinctive elements of services in the public sector that differentiate them from commercial services in the private sector; however, he still argued that public service logic integrates key debates from public administration literature into its discourse.

The purpose of this study was to investigate the gap between arguments derived from public service logic and theories about street-level bureaucracy, using a literature review to problematise public service logic's appropriateness for the development of public sector services. The question under scrutiny was: Can public service logic be an effective recipe for improving the public sector's serviceness? We begin this article by briefly describing the basic elements of service management in which public service logic is anchored. Next, we present three main approaches to public administration before highlighting important issues concerning the nature and aim of the public sector, including theories about street-level bureaucracy and public value. In the main discussion section, we reflect on public service logic's lack of consideration of public sector tasks and the importance of integrating arguments from street-level bureaucracy studies into public service logic to enrich our understanding of public service delivery interactions. Finally, the conclusion summarises the main findings and emphasises the need to develop a model that takes public administration logic into account.

\section{Service Management: New Trends in Marketing Ideas and Practices}

Forty years ago, in the mass consumption era, interactions between organisations and customers were limited. Communication was mainly one-way from organisations to their customers, aiming to convince predefined groups of consumers to buy their products and services, and end users' input was restricted to acceptance or rejection of the products. Value was seen as something internally produced by an organisation and distributed in a market, without any interference by or input from customers.

In the 1990s, the relationship between organisations and their customers changed to become more relationship oriented and based on two-way communication channels. The rapid expansion of information and communication technology made it possible to interact with customers on an individual basis and, thus, to exploit consumers' own knowledge and capability in designing products and services (Wikström 1996). Increased awareness and dialogue with individual customers-combined with a greater focus on intangible services rather than the production of material goods-contributed to the idea of adapting products and services to meet customers' preferences and needs. Users began to engage in developing or modifying products, and user-centric, democratised innovation processes emerged (Von Hippel 2005). The implication was that the customer's role became far more active than it had been up to that point, making the relationships between organ- 
isations and customers even more crucial for creating value (Grönroos and Voima 2013; Prahalad and Ramaswamy 2004).

In 2004, Vargo and Lusch (2004) published an article that identified new trends in marketing ideas and practices, including a shift in focus from outputs and products in a goods-dominant logic to processes and value co-creation in a service-dominant logic. According to service-dominant logic, 'service is defined as the application of competencies (knowledge and skills) for the benefit of another party' (Vargo et al. 2016, p. 129). An important element of service-dominant logic is that services are not specific, manageable goods that businesses and companies produce and distribute to customers; they are processes, and the value of a service is not created until it is used (i.e., the value is created by and in the customer when the service satisfies a desire or need). This means that companies cannot deliver value by themselves; instead, they provide value propositions or participate in the co-creation of value in networks with other actors, who are resource integrators in a service ecosystem where the parties use their specialised knowledge and skills for each other's benefit (Skålén et al. 2018; Vargo and Akaka 2009, 2012). The knowledge and skills of the providers and beneficiaries thus represent the essential source of value (Vargo et al. 2016). In service-dominant logic, all actors-not just individuals and firmsuse their competencies to serve themselves and others by their creation of value through the integration of resources acquired during both economic and social exchanges. Sometimes material goods, such as money and products, are involved in these processes, but goods are seen as appliances for service provision (i.e., they are vehicles or transmitters of service; Vargo et al. 2016).

The role of organisations is to support and assist users' own value-creating processes (Grönroos and Voima 2013; Osborne 2018; Prahalad and Ramaswamy 2004; Skålén et al. 2018). The relationship between service providers and customers is therefore pivotal in servicedominant logic: to gain insight into what the customers perceive as important and valuable, service providers must communicate directly with the users to adapt their value proposition. Providers need to understand customers' value-creating processes in order to adapt their value proposition (Eriksson 2019), and competitive advantage is achieved by creating and maintaining strong, positive, individual experiences among customers. Generating 'repeat business' to retain customers is essential for the profitability of firms. A commercial company's role is no longer limited to providing goods or services to customers; instead, it must design a system of activities within which customers can create their own value (Wikström 1996). Service-dominant logic was originally developed for services in the for-profit sector, but efforts have been made to adapt the perspective to the public sector. Vargo and Lusch $(2008,2016)$ hardly mentioned public services, and the peculiarities of this context have not been elucidated in the service management tradition (Hodgkinson et al. 2017); therefore, it is important to shed light on contextual factors that may affect the opportunities to implement new ideas and practices in other service settings.

\section{Public Administration: The Backdrop of the Discussion}

Today, public administration comprises a mix of approaches introduced at different times. Traditionally, classic public administration was based on a division between politics and administration, with the administration only responsible for implementing decisions of political bodies (Hartley 2005; Osborne and Strokosch 2013). This bureaucratic-legalistic model was intended to be strictly top-down, with frontline employees implementing directives issued by higher levels. Dyadic, two-way interactions with citizens were not mandatory in classic bureaucracy, since communication with users was often written and one-way. Moreover, it was based on decisions made within an organisation, which did not routinely include intentional and active collaboration with citizens. This traditional rule-oriented model has been challenged over time, partly because many public sector employees have professional competence in their field, but also because social developments have made it more common to involve citizens in public processes, such as planning, and in the treatment of their own cases. 
In the late 1970s, the bureaucratic-legalistic model (classic public administration) was challenged for being ineffective — for being 'a big fat cat' (Osborne and Gaebler 1992). Subsequently, new public management became a widespread approach to making the public sector more effective, based on market thinking drawn from the private sector (Christensen and Lægreid 2011). New public management considered users (or clients) to be customers (Hood 1991), and the goal for public services was to meet customers' demands and needs. Competition and tendering out of services were used to ensure better value for the money expended, but competition and the use of contracts sometimes resulted in more rigidity and bureaucracy than under the classic public administration model. Moreover, competition generally means that winners take all (Roberts 2000), and other actors' contributions are not considered.

Despite its adoption (and adaption) in many countries, new public management has not delivered the promised changes (Hood and Dixon 2015). It has been 'flawed in theory and failed in practice to deliver on its promised benefits' (Osborne 2021, p. 177), leading to many public administration scholars declaring new public management obsolete (Torfing et al. 2019). The idea of new public governance therefore gained favour amongst theorists and practitioners (Osborne 2006). In this model, public service organisations were supplemented by public service delivery systems (Osborne and Strokosch 2013), underlining the fact that interactions with multiple actors are needed to achieve stated goals and deliver public services. Learning and knowledge transfer are often easier in collaborative networks (Hartley 2015). Furthermore, other actors, such as private businesses and companies, social entrepreneurs, and voluntary organisations, may have important resources that can be used for the development, production, and improvement of public services (Hartley et al. 2013). The notion of co-creation - the theoretical ground of which was based on the adoption of service management arguments (Baptista et al. 2019) - seemed to capture the core elements of this new public administration paradigm. Torfing et al. $(2019$, p. 802) defined co-creation as 'a process through which two or more public and private actors attempt to solve a shared problem, challenge, or task through a constructive exchange of different kinds of knowledge, resources, competencies, and ideas'.

Three approaches to public administration have been introduced at different times, which can be seen as a linear progression, although they exist side by side (Hartley 2005); hence, 'different generations of public sector reforms have accentuated hybrid and complex features of public organizations' (Christensen and Lægreid 2011, p. 407), resulting in the hybridity causing tension between dissimilar organising principles (Denis et al. 2015). A blend of various principles are used simultaneously in a single organisation, and hybridity can have both advantages and disadvantages regarding the possibilities for implementing new ideas and practices (Sønderskov et al. 2021). Moreover, the term 'governance' implies a downplaying of the traditional governing role of government, together with a playing up of the role of self-regulating networks. However, according to Fenwick et al. (2012), the role of government in public policy and service delivery has not declined; instead, bureaucracy and bureaucratic controls have been extended-something they labelled 'meta-bureaucracy'.

We concluded from this that no single public administration approach was discernible. Nevertheless, we assumed that (1) public service organisations represent the public will, expressed by politicians and interpreted by public employees, and (2) public administration is a tool for realising public value (Benington 2011; Benington and Moore 2011; Moore 1995).

\section{The Nature and Aim of the Public Sector}

In a well-known article, Allison (1983) asked whether private and public organisations are fundamentally alike in multiple respects. Especially during the new public management period, reformers wanted to downplay the differences between the private and public sectors; however, efforts to increase efficiency through the use of market mechanisms have not affected political and institutional differences (Hodgkinson et al. 2017). After studying public sector organisations for several decades, (Christensen et al. 2020) concluded that 
such organisations differ from private organisations in fundamental ways, since they have different purposes and are built on different institutional logics (Thornton and Ocasio 2008).

In representative democracies, public organisations are components of societies' political organisations. This implies a set of public organisations with mandatory membership within a defined geographical area, which, on the one hand, have the authority to collect taxes, impose fines for breaking laws and rules, and in other ways restrict our activities but, on the other hand, also have responsibility for helping citizens (e.g., people with economic deficiencies, health problems, social difficulties, and so on). In contrast to private organisations, where leaders are employed by boards that represent stakeholders, public services and public distribution are subject to elected political bodies, which must provide frameworks for authoritative decision making within given jurisdictions. Elected officials are expected to consider stakeholders' interests, but they are not demand driven or expected to meet 'customers' needs' (Rønning 2017).

Another important difference between private and public organisations is that many public sector organisations are multi-functional and often have to cope with conflicting goals (Christensen et al. 2020); for example, transport authorities usually have to work for better and faster roads, safety, and lower-emission traffic. Consequently, many conflicts of interest exist within public organisations where different actors try to achieve the goals embedded in their individual mandates. Although private organisations can generally be measured on results (production, surplus, etc.), it is more difficult to measure success for public units: sometimes, creating legitimate processes is more important than outcomes (Alford and Greve 2017), and sometimes, public services appear as solutions looking for the issues to which they might be answers (Cohen et al. 1972). While customers in the private sector have to pay for services, that is not (always) the situation for the users of public services. The public sector therefore tends to lack the resources to accomplish its tasks, which has been illustrated by studies on street-level bureaucracy (Lipsky 1980; Hupe and Buffat 2014; Tummers et al. 2015).

\section{Street-Level Bureaucracy and Public Value}

For many citizens, public administration is largely an abstraction until they meet the street-level bureaucrats who represent public services. Interactions with street-level bureaucrats take place when citizens experience the government directly (Lipsky 1980). According to the classic public administration model, street-level bureaucrats, such as police officers, teachers, and social workers, only enforce goals and rules determined at higher levels in the hierarchy; however, such imposed rules may be diffuse or contradictory, and street-level officials must interpret these rules and prioritise the goals and tasks they are expected to fulfil, often because of the shortage of resources to meet the given demands (Bason 2010). Frontline employees in public service organisations must consider various values such as efficiency, fairness, responsiveness, and respect (Zacka 2017); simultaneously, they have bounded rationality, meaning that optimal choices are limited by the organisational actors and their institutional practices (Prior and Marcos-Cuevas 2016). In addition to limited resources, the kind of service they can offer to service receivers may be restricted by how much time they can devote to one user, what they can offer, and other parameters of the service they provide. Hupe and Buffat (2014) highlighted the differences between what is expected of frontline employees (on the demand side) and what is given to them (on the supply side) as the 'public service gap'.

Much of the literature on street-level bureaucracy has dealt with discretion, addressed in terms of coping strategies (Tummers et al. 2015). In his ethnographic fieldwork on anti-poverty agency, Zacka (2017, p. 11) illustrated that street-level bureaucrats are 'vested with a considerable margin of discretion', and this discretionary power makes them moral agents. However, the moral landscape can be difficult to cope with, which results in public officials developing adaptive responses. Tummers et al. (2015) mentioned three methods of coping: 'moving away from clients' (coping for the worker's benefit; i.e., avoiding meaningful interactions), 'moving towards clients' (coping for the client's benefit; i.e., 
pragmatically adjusting to client's need), and 'moving against clients' (coping for the worker's benefit; i.e., by confrontation and rigid rule following). Zacka (2017) also found three matching dispositional orientations among the street-level staff: (1) the indifferent, who wants to process people and get things done as quickly/efficiently as possible; (2) the caregiver, who really wants to help the client and be an advocate for the client with other agencies; and (3) the enforcer, who emphasises controlling the client. While the caregiver will often be a sympathetic listener, the enforcer will be a suspicious one. Zacka (2017) stated that if a street-level service provider sticks to only one of the predispositions at all times, the predisposition can be seen as pathological. The challenge is to decide which disposition the worker should pay most attention to in individual cases: some cases call for a degree of harshness, some require more care, and others are best dealt with indifferently. Street-level bureaucrats must constantly balance the demands of policy implementation with the priorities of the communities they serve (Lipsky 1980; Gofen 2014), meaning that public frontline workers play important roles as decision makers in public value creation.

Moore (1995) introduced the concept of public value. His point of departure was an economic definition of value that saw public value in the public sector as the equivalent of private value in the private sector (Rønning 2017). Benington and Moore (2011) later offered a much broader definition of public value that included social, political, cultural, and environmental dimensions, underlining not only that the public sector is supposed to realise many (and conflicting) goals simultaneously, but also that public value can be realised in many (and conflicting) ways (Rønning 2017). Benington (2011) stated that public value can be thought of in two main ways: (1) what the public values and (2) what adds value to the public sphere. A simple solution to the first demand is that politically elected bodies decide what the public wants, whereas the second demand can be discussed continuously, with many actors contributing to democratic processes. There may be tensions between these understandings, because the latter leads to a wider discussion, emphasising long-term public interests and meaning that public value is a multidimensional construct, created not just through outcomes (the content), but also through dynamic and participatory processes that may generate trust or fairness (O'Flynn 2007). Although public value can be created by any sector, special duty and responsibility lie with public service organisations (Hartley 2015). There is something fundamentally unique about the public sector because of the democratic political context in which public service organisations operate; they are not simply organisations providing a service. Sometimes they must act on behalf of the state (O'Flynn 2007, p. 359) because collective interests are the base, implying that realising public value can be synonymous with ignoring individuals wishes (e.g., regarding the implementation of new rules decided by elected political bodies representing 'the people').

To summarise, public service organisations handle tasks such as assisting people with their problems, protecting citizens, encouraging citizens to obey the laws, and punishing them for violations; thus, public service organisations must engage with complexities that are rarely experienced in the private sector. Nevertheless, it is still important that public services are 'as good, as responsive, as consistent and as fair as possible in meeting public needs' (Donnelly 1999, p. 47). The main aim of public services is to realise public value, which may sometimes align with serving service receivers' interests, but not always. When street-level bureaucrats interact face-to-face with people, they must assess the particularities of each case and behave accordingly. If there are conflicts, public interests are expected to take precedence because of the democratic political context in which public service organisations operate, but this is not always the case in practice; street-level bureaucrats can make rational, ethical, or professional choices when exercising their discretion (Gofen 2014), and overall, research has shown that they cope by 'moving towards clients' (Tummers et al. 2015). Now, we consider how these perspectives might fit with the public service logic model derived from service management. 


\section{Public Service Logic: The Interaction at the Counter}

According to Vargo and Lusch (2016, p. 18), service-dominant logic has five foundational premises: (1) Service is the fundamental basis of exchange; (2) value is co-created by multiple actors, always including the beneficiary; (3) all social and economic actors are resource integrators; (4) value is always uniquely and phenomenologically determined by the beneficiary; and (5) value co-creation is coordinated by actor-generated institutions and institutional arrangements. Applied to public services, we further argue that these fundamental premises can be theoretically and empirically contested.

Firstly, the application of competencies may not always be for the benefit of another; it may also be about control or sanction, such as when people are arrested. Secondly, value is not always co-created; it can also be co-destroyed if the interaction between service providers and users, or between service systems, is mismanaged and results in a decline in individual and/or organisational wellbeing. This applies to both the private and public sectors. Co-destruction occurs when resources are used by one actor in a manner that is not congruent with the way other actors expect them to be used (Echeverri and Skålén 2011; Plé and Cáceres 2010; Prior and Marcos-Cuevas 2016). Disvalue is created 'if the target is different from the one originally intended' (Esposito and Ricci 2015, p. 229). Furthermore, neither creation nor destruction necessarily results from cooperative efforts. Both positive and negative outcomes can be carried out by one of actors alone (Grönroos et al. 2015). Thirdly, resources (knowledge and skills) do not need to be integrated into an interaction, since they can also be destroyed or unused; for example, after the service providers have accessed customers' resources, they 'might not only successfully integrate but also misintegrate the customer's resources with their own' (Plé 2016, p. 159). This may be accidental (e.g., when employees lack the appropriate resources to adapt the service) or intentional (e.g., when employees decide to sabotage the customer's service experience). Fourthly, value is not always determined by the beneficiary; other interests may be seen as more important. In the public sector, the collective value for society can overrule the wishes of some citizens. Finally, according to service-dominant logic, institutions (e.g., norms, rules, meanings, and symbols) are fundamental to our understanding of value co-creation processes because they provide the structural properties we understand as the social context (Vargo and Lusch 2016). In the public sector, however, organisational, structural. and normative frames may be even more influential for enabling and/or constraining value creation. Actor-generated institutions and institutional arrangements may aim to prevent the creation of private value, for example, when the goal is to prevent citizens from using public services to become self-reliant.

In summary, one of the built-in differences between public and private organisations is that a private service can focus on the customer, whereas a public service must always consider fairness and equity, in addition to providing a service to recipients. In applying service-dominant logic to the public sector, Osborne and various colleagues (Osborne et al. 2013, 2016; Osborne and Strokosch 2013; Osborne 2021) became aware of many of these distinctions, and Osborne (2018) mentioned some important differences:

- The retention of customers is important for business firms-while users returning (for instance, to a doctor) may be a sign of an unsatisfactory treatment at the first visit;

- Unwilling customers are almost unknown in the for-profit sector, but not in the public sector (e.g., prisoners and taxpayers);

- For-profit firms usually know who their customers are, but this can be much more complicated for public agencies. Moreover, some public services must be open to anyone wanting to use the service- they are not able to choose their 'customers' (e.g., police, social work, and child welfare services);

- The users of public services are also citizens, voters, and taxpayers with broader societal interest, which may influence their evaluation of the services.

In his latest works, Osborne $(2018,2021)$ stated that he would use Grönroos (2019) version of service management in developing his 'public service logic', distancing himself from Vargo and Lusch $(2008,2016)$ approach. Like service-dominant logic, public service 
logic emphasises processes that increase the wellbeing of users, and creating 'value in use' for those individuals is the goal of services (Engen et al. 2020). Public service logic also emphasises the interaction and interdependence between service providers and service users, wherein users' contributions are crucial to the performance of a service and the impact of the service upon them. Osborne $(2018,2021)$ and Grönroos (2019) concluded that satisfying users and creating private value (as in a market relationship) are the aims of public services. This aligns with five large Horizon 2020 research projects, including Co-Val_-an EU-funded project that aims to find new ways of examining the co-creation of value and its integration in order to transform public services and processes (The Lisbon Council 2021).

\subsection{Co-Creation and Co-Destruction of Value}

In public service logic, the focus on value starts with public service users as value creators, and the question is how users transform a service offering with their resources, skills, and experiences. According to Grönroos (2019), users are in charge of value creation, and they can choose to interact or collaborate with service providers if they so desire. A social worker, for example, can make a service offering by trying to help people to develop their skills and ability to use their own resources; however, how the user interacts and makes sense of this offering will create value in use for them. If users perceive the service offering as inadequate and failing to meet their expectations, service interactions are likely to be characterised by conflict and result in disvalue or value co-destruction. This is an extreme position and ignores, for example, that public health services often save the lives of unconscious patients (Magnussen and Rønning 2021). In such cases, there may be 'added value', but it is not co-created in processes where users are in the front seat.

One main problem with using a public service logic approach, based on service management thinking for the development of public services, is that differences and contradictions between private and public values are ignored. In a public sector context, citizens' welfare maximisation (i.e., satisfying citizens' needs) is not necessarily the objective. Public service organisations play a leading role in creating public value (i.e., by delivering collective value that benefits the citizenry and society at large (Alford 2016; Benington and Moore 2011; Moore 1995)). This should be done 'not only by producingefficiently and effectively-goods and services that can add value to their community but also by pursuing social and ethical goals' (Esposito and Ricci 2015, p. 230), securing social outcomes such as equality and fairness. The creation of public value can align with users' wishes and improve their situations, but that is not necessarily true in all cases; for instance, in March 2020, when the COVID-19 virus was closing down most of the world, we were reminded of this difference. As individuals, we wanted to retain our freedom to move and work, whereas public authorities in many countries were preventing their citizens from traveling and performing their jobs. We must therefore keep in mind that a significant proportion of the interactions between service receivers and providers are not aimed at improving receivers' private value. People who are arrested or sectioned cannot choose whether or how they use service offerings. They are not in charge of value creation-they simply follow the rules (sometimes under physical constraints) imposed by public authorities. If citizens do not behave as expected or according to defined rules (e.g., an unemployed person who does not want to work), public and/or private value may be damaged.

Viewed through a service management lens, and from a service receiver's perspective, interactions that do not add value or improve the receiver's situation are destructive (Echeverri and Skålén 2011; Plé and Cáceres 2010; Prior and Marcos-Cuevas 2016); however, most of the studies focusing on co-destruction have been conducted within private businesses (Engen et al. 2020). Public service failure has attracted less attention than private service failure, 'despite the omnipresence of public service in people's lives and the potential damage public service failure can inflict on their lives' (Tomkins et al. 2020; Van de Walle 2016, p. 831). One exception is Engen et al. (2020) study, which identified four general causes of co-destruction in the public sector: (1) a lack of transparency, (2) mistakes, 
(3) a lack of bureaucratic competence, and (4) an inability to serve. They argued that these incidents causing value co-destruction stem from the accidental misuse of resources for a variety of reasons, such as technical muddles or human-induced confusion. In particular, value is co-destroyed by confusion regarding different actors' roles and responsibilities in a service system.

Public service failures (i.e., co-destruction), however, are not necessarily accidental or considered 'bad' (Edmondson 2011); instead, they are a matter of interpretation and perception-'in the eyes of the beholder' (Van de Walle 2016, p. 833). To illustrate this, providing professional help/support is an important task in the public sector. Citizens expect that public service providers will take relevant professional knowledge into account in their decision making, but the professional conclusions may not align with individuals understanding of their situations; for example, it is not necessarily a good thing to allow an alcoholic patient access to alcohol, even if this is what the user wants. Professional decisions may result in intended value destruction, which is both correct and appropriate in certain situations. Since most of the existing research has focused on service users, street-level bureaucrats' discretionary choices in service delivery have been largely ignored. There is a need to broaden the application of public service logic beyond the 'customer' sphere (Hodgkinson et al. 2017) and to extend public service logic by explicitly recognising the social context, because social structures support and constrain the prerequisites for citizens' actions and interactions. These structures can explain disparities between groups when they meet the state as public service users-some people face barriers, while others do not (e.g., depending on user characteristics, the professions of the staff, and the type of public service; Eriksson 2019, p. 308).

Frontline employees' roles are crucial, since they must interact directly with service users as value advocators and facilitators, build relationships and trust with several actors in the service system (users, their families, a third sector, etc.), and promise certain processes or experiences (Osborne and Strokosch 2013). Frontline staff in public service organisations can have either positive or negative effects on service experience (Osborne 2021; Skålén et al. 2018), especially regarding how they affect users' willingness or motivation to interact with them in value-creating activities; thus, it is important to examine how public professionals view themselves and their responsibilities in service delivery (Steen and Tuurnas 2018).

\subsection{Public Service Logic versus Public Administration Logic}

When discussing the possibility of public service organisations becoming more userfriendly, Grönroos (2019, p. 787) concluded that accomplishing this goal is a matter of having visionary people who understand what it takes to be service oriented and have the courage and strength to implement their vision. However, public service organisations seek to address complex values, which require a balance of responsibilities, often within budgetary constraints (Bason 2010). Because public services do not choose their 'markets' or 'customers', they have to respond to whatever situations are presented to them, so demand is always an issue-and rationing demand is sometimes necessary. Walley (2013) illustrated that public services are 'resource-driven' rather than 'demand-driven': in the public sector, demand increases are seen 'as a further drain on the (limited) resource pool' (p. 884). This contrasts with the private sector, which can either expand to address demand or can limit demand. In private service organisations, demand increases are opportunities to make more profit, and resources are configured around the need to meet these desirable demands. By contrast, public sector organisations are driven by their tasks, their environment, and the capacities they need to solve complex problems, such as climate change, homelessness, economic restructuring, pandemics, and so on.

Street-level bureaucracy studies have considered the limitations that characterise organisational and institutional frames for public frontline employees and decision makers. Frontline employees must respond to a multitude of normative demands, trying to meet the needs of users while simultaneously considering and managing the expecta- 
tions of multiple social actors, including communicating decisions of political authorities. Whatever they do, they can be accused of not meeting goals. Additionally, they are often burdened with heavy workloads and bounded rationality, meaning that opportunities to make optimal choices are limited (Prior and Marcos-Cuevas 2016). Street-level divergence is considered inevitable (Gofen 2014), which has been mentioned in many studies on public administration, such as the much-cited example of Simon's classic study of 'administrative behavior' (Simon 1965). Street-level bureaucrats have some power to define and choose values and goals (Zacka 2017), and such discretion can have positive effects for users: if street-level bureaucrats perceive their work as meaningful and want to make a difference in users' lives (e.g., as caregivers), they may work to expand opportunities to help people (Tummers and Bekkers 2014), but this also means that they are burdened with moral agency and responsibilities. Drawing on the 'citizen agent narrative' in decisions about resource allocation in service delivery may conflict with the 'state agent narrative', which addresses law abidance and fidelity to administrative rules and supervision (Tummers et al. 2015, p. 1112).

Public sector organisations are expected to achieve many and sometimes contradictory goals simultaneously, and a continuous battle between different interests ensues (Christensen et al. 2020); for instance, street-level bureaucrats can be seen as upholders of high ethical standards but may simultaneously face conflicting expectations from their managers (e.g., to use economic sanctions as a tool to improve the willingness of unemployed welfare recipients to participate in job-seeking activities within the framework of active labour market policy). In such cases, professional norms can be compromised by organisational infrastructures (Caswell and Høybye-Mortensen 2015). This illustrates an important point: political decisions may provide guidelines for service providers to ensure that user-friendliness does not undermine public service policy (e.g., to discourage users from returning); therefore, a weakness of public service logic is that the model overlooks political factors.

Political goals and visions (i.e., what decision makers define as public value at a certain time) vary according to different political constellations, but also as a consequence of complex new challenges. Value creation processes in the public sector may be a site of struggle on a political playground in which multiple interests need to be recognised as a component of public decision making. Criteria for success and failure are, therefore, ambiguous: 'Public services can fail without this being seen as such, and they can succeed without being recognized as such' (Van de Walle 2016, p. 833). As an alternative to focusing on performance and optimised outcome, more attention should be paid to engaging with citizens and other stakeholders in forming and shaping public value propositions (Alford and Greve 2017). Moreover, instead of seeing a social context as an 'add on' to the public service logic approach, in line with Eriksson (2019), we consider it important to see the context, the users, and the street-level bureaucrats as parts of an integrated system. Even users can be fundamentally different for public and private services-users appear in different roles, according to time and situation, and the context that surrounds those individuals is affected by constant political changes. Furthermore, professional frontline employees must adopt dispositional orientation and coping strategies depending on the situation. Discretion may have negative effects caused by factors at the meso and macro levels, not only in terms of policy implementation hurdles, but also in terms of negative outcomes for service users (Nothdurfter and Hermans 2018). Traditionally, professionalism is based upon the wielding of power rather than upon partnerships, which may in itself be a barrier to public service logic (Osborne 2021). However, studies on street-level bureaucrats have shown that frontline employees overall cope by 'moving towards clients' (Tummers et al. 2015).

In Table 1, we summarise the main differences between the contradictory elements of public administration logic and public service logic. 
Table 1. Differences between public administration logic and public service logic.

\begin{tabular}{lcc}
\hline & Public Administration Logic & Public Service Logic \\
\hline Focus & Citizens as a collective & Individual users \\
\hline Goal & Creating public value & Creating private value \\
\hline Co-creation & Various degrees & Unavoidable and/or necessary \\
\hline Service Providers & Moral agents & User friendly \\
\hline Purpose & Multi-purpose & Uni-purpose \\
\hline Narrative & State agent & Citizen agent \\
\hline
\end{tabular}

In this discussion of serviceness in the public sector, we have not distinguished between different public services delivered to citizens, although they can be highly dissimilar. It is important to note that the roles of users and service providers depend heavily on the services offered, and this should be elaborated further. Here, we mention two main categories of public services that have different implications for the importance of co-creation processes. A basic distinction can be made between (1) help/support (healthcare, social services, education, etc.) and (2) maintenance of established rules (traffic rules, tax laws, authorities, etc.). In the first category, it is important to interact directly with users to understand their needs and wishes-and the outcomes will certainly depend on co-creation and service providers' dispositional orientations, competencies, and professional choices. In the second category, outcomes are based on rules and laws: processes should be legitimate and fair, but value from these services cannot be co-created. Therefore, in the public sector, users can be invited to participate in value co-creation (to various degrees) for services intended to help/support. For services that build on legal interpretation, the final word goes to the relevant bureaucracy (governed by politicians), because governing bodies are mandated to achieve political goals dictated by democratic electorates.

\section{Conclusions}

In this article, we have investigated the gap between arguments derived from public service logic and theories about street-level bureaucracy. Public service logic is based on a generic service-dominant concept (Alford 2016), whereby customers interact with service systems as individuals. However, these theoretical approaches do not truly consider the context of public services (e.g., where users appear in different roles, as users of the service but also as taxpayers financing services, and where different end users may have different definitions of successful outcomes; Osborne and Strokosch 2013; Osborne 2018, 2021). Therefore, we asked whether public service logic could be an appropriate recipe for improving public sector serviceness.

Based on our literature review, we identified several contextual factors that may create problems when introducing public service logic as a way to develop public services. Public service logic is anchored in the service management tradition (Osborne 2021), which aims to satisfy users and create private value (Engen et al. 2020; Osborne 2018, 2021; Grönroos 2019). Elements from this tradition have probably helped public sector organisations to become more aware of their users' active role as co-creators. However, because of the distinctiveness of public services operating in representative democracies, the main aim of public service organisations is to create public value (i.e., collective value that benefits society overall (Alford 2016; Moore 1995)). This necessitates moving beyond market thinking (what the customer wants/needs) towards focusing on what the public values and what creates value in the public sphere. On the political battlefield, individual users' interests are legitimate, but many other interests must be considered. Public value has many dimensions (social, political, cultural, and environmental), and the creation of public value does not always align with private value creation and the service users' wishes or needs (Benington and Moore 2011). Furthermore, street-level bureaucrats' choices and coping strategies have great significance for and great influence on the interactions between users 
and service providers in the public sector. That means that it is not a lack of intelligence or receptiveness among public service providers or managers that causes decisions to be misaligned with users' choices (according to Grönroos and Osbornes' arguments), but the fact that the public sector has to try to recognise and manage many conflicting values simultaneously.

Public sector logic ignores important aspects of the public sector; therefore, we argue that the model cannot contribute to the development of more serviceness in this context, because such a model must build on the characteristics that justify having a public sector. A starting point for further research could be to stop considering users as individuals and start considering citizens as a collective. Being a 'public customer' means being part of the collective citizenship, accepting decisions made by the public authorities and, sometimes, political decisions that imply the (co-)destruction of value. A well-functioning public service sector meets the wishes of a collective through its interactions with users. In helping and supporting people, the public sector must consider private interests but place individuals in a context. Inevitably, many public services have to maintain rules and laws, with the outcomes of service delivery decided in advance and leaving little room for the co-creation/co-destruction of value.

In addition to helping and supporting frail groups by distributing resources fairly and acceptably, public sector organisations need to take into account accepted public values (transparency, equal treatment, etc.) in order to design well-functioning democratic processes for dealing with complicated issues, thereby ensuring support and legitimacy of the public authority.

Efforts to improve public services that do not take into account the realisation of public value as a main democratic task will be ineffective: 'Politics remains the final arbiter of public value, just as private consumption decisions remain the final arbiter of private value' (Moore 1995, p. 38). We hope our perspective will contribute to 'bringing the state back in' (Evans et al. 1985), emphasising the importance of politics in studies on value co-creation in the public sector. As the famous remark of Sir Paul Hasluck highlighted, it is important to remember that 'the public service cannot avoid politics any more than fish can avoid the water in which they swim' (Keating 1999, p. 44).

Author Contributions: Both authors have contributed equally to this paper. Both authors have read and agreed to the published version of the manuscript.

Funding: This project has received funding from the European Union's Horizon 2020 research and innovation programme under grant agreement [No 770356]. This publication reflects the views only of the authors, and the Agency cannot be held responsible for any use, which may be made of the information contained therein.

Acknowledgments: The authors wish to thank Jean Hartley, Professor at The Open University, for being a valuable discussion partner and commentator.

Conflicts of Interest: The authors declare no conflict of interest.

\section{References}

Alford, John. 2016. Co-production, interdependence and publicness: Extending public service-dominant logic. Public Management Review 18: 673-91. [CrossRef]

Alford, John, and Carsten Greve. 2017. Strategy in the public and private sectors: Similarities, differences and changes. Administrative Sciences 7: 35. [CrossRef]

Allison, Graham T. 1983. Public and private management: Are they fundamentally alike in all unimportant respects? In Public Management. Edited by James L. Perry and Kenneth L. Kraemer. California City: Mayfield Publishing Company, pp. $72-92$.

Baptista, Nuno, Helena Alves, and Nelson Matos. 2019. Public Sector Organizations and Cocreation with Citizens: A Literature Review on Benefits, Drivers, and Barriers. Journal of Nonprofit and Public Sector Marketing 32: 1-25. [CrossRef]

Bason, Christian. 2010. Leading Public Sector Innovation: Co-Creating for a Better Society. Bristol: The Policy Press. [CrossRef]

Benington, John. 2011. From private choice to public value? In Public Value. Theory and Practice. Edited by John Benington and Mark H. Moore. London: Palgrave Macmillan, pp. 31-49. [CrossRef]

Benington, John, and Mark H. Moore. 2011. Public value in Complex and Changing Times. In Public Value. Theory and Practice. London: Palgrave Macmillan, pp. 1-30. [CrossRef] 
Caswell, Dorte, and Matilde Høybye-Mortensen. 2015. Responses from the frontline: How organisations and street-level bureaucrats deal with economic sanctions. European Journal of Social Security 17: 31-51. [CrossRef]

Christensen, Tom, and Per Lægreid. 2011. Complexity and hybrid public administration—Theoretical and empirical challenges. Public Organization Review 11: 407-23. [CrossRef]

Christensen, Tom, Per Lægreid, and Kjell Arne Røvik. 2020. Organization Theory and the Public Sector: Instrument, Culture and Myth. New York: Routledge.

Cohen, Michael D., James G. March, and Johan P. Olsen. 1972. A garbage can model of organizational choice. Administrative Science Quarterly 17: 1-25. [CrossRef]

Denis, Jean-Louis, Ewan Ferlie, and Nicolette Van Gestel. 2015. Understanding hybridity in public organizations. Public Administration 93: 273-89. [CrossRef]

Donnelly, Mike. 1999. Making the difference: Quality strategy in the public sector. Managing Service Quality: An International Journal 9: 47-52. [CrossRef]

Echeverri, Per, and Per Skålén. 2011. Co-creation and co-destruction: A practice-theory based study of interactive value formation. Marketing Theory 11: 351-73. [CrossRef]

Edmondson, Amy C. 2011. Strategies for learning from failure. Harvard Business Review 89: 48-55.

Engen, Marit, Martin Fransson, Johan Quist, and Per Skålén. 2020. Continuing the development of the public service logic: A study of value co-destruction in public services. Public Management Review 23: 886-905. [CrossRef]

Eriksson, Erik M. 2019. Representative co-production: Broadening the scope of the public service logic. Public Management Review 21: 291-314. [CrossRef]

Esposito, Paolo, and Paolo Ricci. 2015. How to turn public (dis)value into new public value? Evidence from Italy. Public Money and Management 35: 227-31. [CrossRef]

Evans, Peter B., Dietrich Rueschemeyer, and Theda Skocpol. 1985. Bringing the State Back In. Cambridge: Cambridge University Press. [CrossRef]

Fenwick, John, Karen Johnston Miller, and Duncan McTavish. 2012. Co-governance or meta-bureaucracy? Perspectives of local governance 'partnership' in England and Scotland. Policy \& Politics 40: 405-22. [CrossRef]

Gofen, Anat. 2014. Mind the gap: Dimensions and influence of street-level divergence. Journal of Public Administration Research and Theory 24: 473-93. [CrossRef]

Grönroos, Christian. 2019. Reforming public services: Does service logic have anything to offer? Public Management Review 21: 775-88. [CrossRef]

Grönroos, Christian, and Päivi Voima. 2013. Critical service logic: Making sense of value creation and co-creation. Journal of the Academy of Marketing Science 41: 133-50. [CrossRef]

Grönroos, Christian, Tore Strandvik, and Kristina Heinonen. 2015. Value co-creation: Critical reflections. In The Nordic School. Service Marketing and Management for the Future. Edited by Johanna Gummerus and Catharina von Koskull. Helsinki: CERS Hanken School of Economics, pp. 69-81.

Hartley, Jean. 2005. Innovation in governance and public services: Past and present. Public Money and Management 25: 27-34.

Hartley, Jean. 2015. The creation of public value through step-change innovation in public organizations. In Public Value and Public Administration. Edited by John M. Bryson, Barbara C. Crosby and Laura Bloomberg. Washington: Georgetown University Press, pp. 82-94.

Hartley, Jean, Eva Sørensen, and Jacob Torfing. 2013. Collaborative innovation: A viable alternative to market competition and organizational entrepreneurship. Public Administration Review 73: 821-30. [CrossRef]

Hodgkinson, Ian R., Claire Hannibal, Byron W. Keating, Rosamund Chester Buxton, and Nicola Bateman. 2017. Toward a public service management: Past, present, and future directions. Journal of Service Management 28: 998-1023. [CrossRef]

Hood, Christopher. 1991. A public management for all seasons? Public Administration 69: 3-19. [CrossRef]

Hood, Christopher, and Ruth Dixon. 2015. A Government That Worked better and Cost Less?: Evaluating Three Decades of Reform and Change in UK Central Government. Oxford: Oxford University Press.

Hupe, Peter, and Aurélien Buffat. 2014. A public service gap: Capturing contexts in a comparative approach of street-level bureaucracy. Public Management Review 16: 548-69. [CrossRef]

Keating, Michael. 1999. The public service: Independence, responsibility and responsiveness. Australian Journal of Public Administration 58: 39-47. [CrossRef]

Lipsky, Michael. 1980. Street-Level Bureaucracy: Dilemmas of the Individual in Public Services. New York: Russell Sage Foundation. [CrossRef]

Magnussen, Siv, and Rolf Rønning. 2021. Creating value in public services: The struggle between private and public interests? The Innovation Journal: The Public Sector Innovation Journal 26: 1.

Moore, Mark H. 1995. Creating Public Value: Strategic Management in Government. Harvard: Harvard University Press.

Nothdurfter, Urban, and Koen Hermans. 2018. Meeting (or not) at the street level? A literature review on street-level research in public management, social policy and social work. International Journal of Social Welfare 27: 294-304. [CrossRef]

O'Flynn, Janine. 2007. From new public management to public value: Paradigmatic change and managerial implications. Australian Journal of Public Administration 66: 353-66. [CrossRef]

Osborne, Stephen P. 2006. The new public governance? Public Management Review 8: 377-87. [CrossRef] 
Osborne, Stephen P. 2018. From public service-dominant logic to public service logic: Are public service organizations capable of co-production and value co-creation? Public Management Review 20: 225-31. [CrossRef]

Osborne, Stephen P. 2021. Public Service Logic: Creating Value for Public Service Users, Citizens, and Society Through Public Service Delivery. New York: Routledge. [CrossRef]

Osborne, David E., and Ted Gaebler. 1992. Reinventing Government: How the Entrepreneurial Spirit Is Transforming the Public Sector. Boston: Addison-Wesley.

Osborne, Stephen P., and Kirsty Strokosch. 2013. It takes two to tango? Understanding the co-production of public services by integrating the services management and public administration perspectives. British Journal of Management 24: 31-47. [CrossRef]

Osborne, Stephen P., Zoe Radnor, and Greta Nasi. 2013. A new theory for public service management? Toward a (public) servicedominant approach. The American Review of Public Administration 43: 135-58. [CrossRef]

Osborne, Stephen P., Zoe Radnor, and Kirsty Strokosch. 2016. Co-production and the co-creation of value in public services: A suitable case for treatment? Public Management Review 18: 639-53. [CrossRef]

Plé, Loïc. 2016. Studying customers' resource integration by service employees in interactional value co-creation. Journal of Services Marketing 32: 152-64. [CrossRef]

Plé, Loïc, and Rubén Chumpitaz Cáceres. 2010. Not always co-creation: Introducing interactional co-destruction of value in servicedominant logic. Journal of Services Marketing 24: 430-37.

Prahalad, Coimbatore K., and Venkat Ramaswamy. 2004. Co-creation experiences: The next practice in value creation. Journal of Interactive Marketing 18: 5-14. [CrossRef]

Prior, Daniel D., and Javier Marcos-Cuevas. 2016. Value co-destruction in interfirm relationships: The impact of actor engagement styles. Marketing Theory 16: 533-52. [CrossRef]

Roberts, Alasdair S. 2000. Less government, more secrecy: Reinvention and the weakening of freedom of information law. Public Administration Review 60: 308-20. [CrossRef]

Rønning, Rolf. 2017. Innovation and the creation of public value. In Administrative Strategies of Our Time. Edited by Noralv Veggeland. New York: Nova Science Publishers, pp. 69-94.

Simon, Herbert A. 1965. Administrative Behavior: A Study of Decision-Making Processes in Administrative Organization, 2nd ed. Bingley: Free Press.

Skålén, Per, Jenny Karlsson, Marit Engen, and Peter R. Magnusson. 2018. Understanding public service innovation as resource integration and creation of value propositions. Australian Journal of Public Administration 77: 700-14. [CrossRef]

Sønderskov, Mette, Rolf Rønning, and Siv Magnussen. 2021. Hybrid stimulations and perversions in public service innovation. Public Policy and Administration. [CrossRef]

Steen, Trui, and Sanna Tuurnas. 2018. The roles of the professional in co-production and co-creation processes. In Co-Production and Co-Creation: Engaging Citizens in Public Services. Edited by Taco Brandsen, Bram Verschuere and Trui Steen. New York: Routledge, pp. 80-92.

The Lisbon Council. 2021. The Co-Creation Compass, Issue 27/2021. Available online: https:/ / lisboncouncil.net/wp-content/uploads/ 2021/04/LISBON_COUNCIL_The-Co-Creation-Compass.pdf (accessed on 23 April 2021).

Thornton, Patricia H., and William Ocasio. 2008. Institutional logics. In The Sage Handbook of Organizational Institutionalism. Edited by Royston Greenwood, Christine Oliver, Thomas B. Lawrence and Renate E. Meyer. London: Sage, pp. 99-129. [CrossRef]

Tomkins, Leah, Jean Hartley, and Alexandra Bristow. 2020. Asymmetries of leadership: Agency, response and reason. Leadership 16: 87-106. [CrossRef]

Torfing, Jacob, Eva Sørensen, and Asbjørn Røiseland. 2019. Transforming the public sector into an arena for co-creation: Barriers, drivers, benefits, and ways forward. Administration \& Society 51: 795-825.

Tummers, Lars, and Victor Bekkers. 2014. Policy implementation, street-level bureaucracy, and the importance of discretion. Public Management Review 16: 527-47. [CrossRef]

Tummers, Lars LG, Victor Bekkers, Evelien Vink, and Michael Musheno. 2015. Coping during public service delivery: A conceptualization and systematic review of the literature. Journal of Public Administration Research and Theory 25: 1099-126. [CrossRef]

Van de Walle, Steven. 2016. When public services fail: A research agenda on public service failure. Journal of Service Management 27: 831-46. [CrossRef]

Vargo, Stephen L., and Melissa Archpru Akaka. 2009. Service-dominant logic as a foundation for service science: Clarifications. Service Science 1: 32-41. [CrossRef]

Vargo, Stephen L., and Melissa Archpru Akaka. 2012. Value cocreation and service systems (re) formation: A service ecosystems view. Service Science 4: 207-17. [CrossRef]

Vargo, Stephen L., and Robert F. Lusch. 2004. Evolving a services dominant logic. Journal of Marketing 68: 1-17. [CrossRef]

Vargo, Stephen L., and Robert F. Lusch. 2008. Service-dominant logic: Continuing the evolution. Journal of the Academy of Marketing Science 36: 1-10. [CrossRef]

Vargo, Stephen L., and Robert F. Lusch. 2016. Institutions and axioms: An extension and update of service-dominant logic. Journal of the Academy of Marketing Science 44: 5-23. [CrossRef]

Vargo, Stephen L., Robert F. Lusch, and Kaisa Koskela-Huotari. 2016. Service-dominant Logic. Marketing Theory: A Student Text. Thousand Oaks. London: Sage.

Von Hippel, Eric. 2005. Democratizing Innovation: The Evolving Phenomenon of User Innovation. Cambridge: The MIT Press. [CrossRef] 
Walley, Paul. 2013. Does the public sector need a more demand-driven approach to capacity management? Production Planning $\mathcal{E}$ Control 24: 877-90.

Wikström, Solveig. 1996. Value creation by company-consumer interaction. Journal of Marketing Management 12: 359-74. [CrossRef]

Zacka, Bernardo. 2017. When the State Meets the Street. Public Service and Moral Agency. Harvard: Harvard University Press. [CrossRef] 